\title{
Lacuna of Primary Skills Among High School Students of South Coastal Districts in Andhra Pradesh
}

\section{Palle Manohar}

Research Scholar, Dept. of English

Acharya Nagarjuna University

Guntur, Andhra Pradesh, India

manoharpalle22@gmail.com

Dr.G.Chenna Reddy

Asso.Prof, Dept. of English

Acharya Nagarjuna University

Guntur, Andhra Pradesh, India

crgujju27@gmail.com

\section{Introduction}

The present paper covers the teaching and learning process of English language teaching in government schools of Andhra Pradesh. As the aim of the syllabus by the SCERT, Andhra Pradesh, the learners of English are expected to achieve proper communication skills to apply it in the global context. Bright and Marc Gregor (1978) have remarked that "there is no language learning without exposure" At this juncture mere knowledge of English, based upon listening, speaking, reading and writing directed towards acquisition of communication skills among high school students. The present study intended to find out the lacuna of primary skills in English language among the students at high school level. An Oxford dictionary defines lacuna as 'an absent part'. This paper portrays the percentage of expected and 
DOI: https://doi.org/10.24113/ijellh.v9i2.10920

achieved skills of the students which is technically the term called as 'Lacuna'. Most of the students are promoted to the next classes without achieving all the skills expecting by the SCERT. Gradually the difference between expected and achieved skills have been increasing by the students year by year. At this juncture, it is very much needed to fill the lacuna between expected and achieved skills among the students for the strong foundation of the students in the field of communication skills.

Keyword: Communication, Listening Skill, Speaking Skill, South Coastal, Teaching Methods, Lacuna.

Statement of the problem:

The researcher finds out the practical problems of English learners. As the researcher experienced personally different problems in learning English language at secondary school level, the Researcher proposed to estimate the lacuna of primary skills of the students of selected schools among Guntur, Prakasam and Krishna districts in Andhra Pradesh. The Researcher further planned to compare certain socio-economical, Gender and Geographical problems of the English learners. To compare the achievement levels, the Researcher planned to include the ability in vocabulary, grammar, listening skill, speaking skill, reading skill and writing skill.

Purpose of the study:

To know the basic reason for lack of sufficient communication skills among Indian students in general and high school students in Guntur Prakasam and Krishna districts in Andhra Pradesh particular. It is assumed that there are different reasons including gender, socio-economical and geographical reasons to have inadequate communication skills in English language. Sometimes it appears that the social and economic background play a very important role in the academic progress of a student. Socially and economically backward learners stand behind to those who are forward both socially and economically. It is 
DOI: https://doi.org/10.24113/ijellh.v9i2.10920

necessary to know the reasons of socio-economical forward learners to have better communication skills if they are compared to those who are lagging behind both socially and economically. Urban area students have an advantage of having better communication skills if they are compared to semi-urban or rural area students. It is necessary to know the reasons for such differences of communication skills among urban, semi-urban or rural area students. It is needed to find out whether there is any gender factor to have communication skills between male and female.

Importance of primary skills in English:

LSRW aptitudes impact the accomplishment of a person. The four noteworthy abilities of language getting the hang of, tuning in, talking, perusing and composing offer the exact key to progress. Instructing of English language while ensuring accentuation on all these four abilities offer a phase for the students to improve their skill in this language well. Listening, speaking, reading and writing are called skills in language. Listening and speaking are known as primary skills because even an illiterate also can be master over primary skills. Whereas the secondary skills like reading and writing need some training and practice to be master over secondary skills.

Listening skill:

Listening is the primary skill to learn a language. Of course we learnt our mother tongue, as the child knows nothing about language and the child completes much of the first language acquisition process within the first five years, depending exclusively on listening. Nothing can be promenade unless it is listened. A born deaf cannot utter a sentence because he listens nothing. A Child lisps to imitate the parents or elders often a repeated listening. Students recite again and again the same word taught by the teacher after careful listening in the classroom at the primary level. A good listener can develop a clear cognitive map in his mind and imitate or use the same sound when the occasion demands. As the first and the 
DOI: https://doi.org/10.24113/ijellh.v9i2.10920

foremost skill of a language acquisition the role of listening skill is essential in classroom. Listening, skill also plays the same role in the second language or the foreign language acquisition. The process of learning foreign language or second language includes discovering the rules of phonology, syntax, semantics and pragmatics.

According to the book 'Methods of Teaching English' listening ability can be cultivated through continues listening practice, both extensive and intensive. Extensive listening deals with exposure to a wide variety of structures and sounds. This type of listening makes the children to listen with understanding the language in their real life situations. In the same way, Intensive listening concern with just one or two specific points.

Coackly \& Wolvin are listed out about the types of listening in the book called 'A Listening Taxonomy' (1982). Majorly they have identified five types of listening in general they are 1. Discriminative listening, 2. Comprehensive listening, 3. Critical Listening, 4. Persuasive Listening, 5. Appreciative listening.

Normally listening procedure starts when the audience focuses on some capable of being heard sounds and flag, simultaneously allows him to translate those sounds which he had listened intentionally. Each person has the characteristic capacity to choose the sounds around him. Be that as it may, the particular listening may not programme like hearing. An individual can listen to numerous sounds yet he may tune in to none of them.

Listening is only a demonstration of mindful hearing. In common, each individual spends his/her $45 \%$ of time on tuning in. We listen more than the talking. In the event that we may ace over the listening aptitude consequently we can be ace over different instruments of relational abilities. Listening procedure is troublesome as human personality bothers effectively. The person, who controls his mind and listens attentively and need to acquire other skills also. 
DOI: https://doi.org/10.24113/ijellh.v9i2.10920

"Listening ability lies at the heart of all growth, from birth through the years of formal education. The better those learning skills are developed, the more productive our learning efforts,"

- James Brown.

Tuning in with consideration makes the individual effective in work spot, family and in the general public. Great listening abilities are mandatory to get into a calling in correspondences, the board, arranging, and deals some other action and so on, it includes various dialogues, addressing for clarifications, indicating articulations and giving reasonable reaction. Great listening aptitudes are additionally included with getting capacity. Non-verbal communication likewise goes under the piece of the listening ability.

There are five phases associated with the listening aptitude i.e., Receiving, Understanding, Remembering, Evaluating, and Responding. These are the most regularly alluded in listening procedure to break down great correspondence since it helps exclusively the important abilities required to one another.

As the present age seems to be 'the hurrying to the spot' and the contemporary man has no opportunity to stand and gaze, one might not have quite a while to listen articulations. Be that as it may, one cannot learn numerous things without tuning in. Be that as it may, listening has incredible significance in language securing. There is no uncertainty language learning starts with tuning in. As listening assumes a key job in learning first language, it likewise assumes a similar job in the subsequent language or unknown dialect securing. Speaking skill:

Speaking is fundamentally a gainful expertise. Talking is helped by certain highlights like pressure, inflection which go with the communicated in language articulation and from the piece of its significance, outward appearances and body developments. At the point when 
DOI: https://doi.org/10.24113/ijellh.v9i2.10920

the talking is going on by any speaker, it is certain that he has been including in the correspondence procedure with some reason.

"The ability to speak a language is synonymous with knowing that language. Nevertheless, speaking in a second or foreign language has often been viewed as the most demanding of four skills," says Baily \& Savage.

Speaking is a movement requiring the mix of many sub frameworks. Every one of these variables consolidate to make talking a second or unknown dialect an impressive for language students. Since the language is discourse, the most fundamental methods for human correspondence are language. Talking is an action requiring the incorporation of many sub frameworks like pressure, cadence, pitch, clearness of discourse and so forth. Talking is considered as a difficult and focal ability of the language.

"Speaking is an interactive process of constructing the meaning that involves producing, receiving, and processing the information," Brown.

Around the globe, youngsters need to go to class however tragically, the vast majority of the kids and youths in creating nations face boundaries to getting quality training. For some it might be one snag, for other people, there are numerous obstacles to bounce to have the option to go to class. Destitution is the most unavoidable factor keeping kids from going to class. Poor families are less ready to bear the cost of school charges, garbs and course books for the majority of the high school students. A kid in school cannot work to help bolster the family, and they have less time to help with family unit tasks like bringing water. They are additionally substantially less prone to finish grade school. This boundary to instruction strengthens the cycle of destitution with the goal that the poor remain poor. A tyke experiencing childhood in a country network is likewise off guard in instructive chances and the hole among provincial and urban kids can be extremely enormous. A youngster growing up communicating in a minority language is more averse to adapt well when school is not led 
DOI: https://doi.org/10.24113/ijellh.v9i2.10920

in her primary language. This prompts higher dropout rates and a circumstance where minorities become minimised and prohibited. At long last, numerous high school students face covering obstructions to instruction: a poor, rustic young lady is among the most unrealistic on the planet to have the option to go to grade school and to finish her examinations.

Objectives:

1. To examine the Lacunae between the syllabus expectations and actual learning of LSRW skills among High School students.

1) To find out the lacuna of syllabus expectations and actual learning of LSRW skills among IX class students of their VIII standard students in the South Coastal Andhra Pradesh.

2) To find out the lacuna of syllabus expectations and actual learning of Listening skills among IX class students of their VIII standard students in the South Coastal Andhra Pradesh.

Methodology

The scope of the study is limited to the high school students of Guntur, Prakasam and Krishna districts in Andhra Pradesh. 360 students were taken to estimate their lacuna of communication skills in English. Further it is limited to calculate the lacuna of listening and speaking skills in English language. The students were taken belonging to different geographical places like urban, semi-urban and rural areas. Geographically Guntur, Prakasam and Krishna located beside the coastal area of Andhra Pradesh.

A total of 360 students are involved in this research survey. The data collection will be done through the use of a survey questionnaire. 360 students are selected randomly as the sample of the study. The sample consisted of 9 high school students who is studying their IX standard. 40 students were selected from each school, among forty students, twenty students 
DOI: https://doi.org/10.24113/ijellh.v9i2.10920

were male and the remaining twenty were female. Students from different social sectors, economical background, male and female also involved in this study. The study is conducted through the help of a test and teachers questionnaire. The questions in the questionnaire are divided into two sections; the first part consisted of questions concerning personal information and the second part of the questionnaire included listening skill, reading skill, and speaking skill, writing skill and grammar \& vocabulary. The below tables show the participants were involved in the study from the three districts of Andhra Pradesh.

Listening activity has been the most neglected area among the four language skills of the English at school level. It is noticed, due to misconception forced by many of us that this skill is imbibed with mental maturity (Dr.S.Priya). Listening skill can be acquired through the natural way just as the child learns its own mother tongue. But, since the students unable to listen English in the natural environment, Practice is the best method to be master over the listening skill in English language.

The acquisition of speaking skill in classroom situation seems to be satisfactory in the existing scenario at the high level of Andhra Pradesh. Introducing English medium at high school level leads to large theory classes where the lecturing method has been following today. As a result, there is a scope to practice speaking skill by the students in the classroom premises. 
DOI: https://doi.org/10.24113/ijellh.v9i2.10920

Data Analysis

Table 1.1.- The lacuna of overall listening skill among VIII class students of Guntur, Krishna and Prakasam districts

\begin{tabular}{|c|c|c|c|c|c|c|c|c|c|c|c|c|c|}
\hline \multirow[t]{2}{*}{$\begin{array}{c}\text { S. } \\
\text { No }\end{array}$} & $\begin{array}{l}\text { Name } \\
\text { of The }\end{array}$ & \multicolumn{3}{|c|}{ Guntur } & \multicolumn{3}{|c|}{ Krishna } & \multicolumn{3}{|c|}{ Prakasam } & \multicolumn{3}{|c|}{$\begin{array}{c}\text { Average } \\
\text { Percentage }\end{array}$} \\
\hline & School & $\begin{array}{l}\text { Aver } \\
\text { age } \\
\text { Secu } \\
\text { red } \\
\text { Mar } \\
\text { ks }\end{array}$ & $\%$ & $\begin{array}{l}\text { Lac } \\
\text { una }\end{array}$ & $\begin{array}{l}\text { Aver } \\
\text { age } \\
\text { Secu } \\
\text { red } \\
\text { Mar } \\
\text { ks }\end{array}$ & $\%$ & $\begin{array}{l}\text { Lac } \\
\text { una }\end{array}$ & $\begin{array}{l}\text { Aver } \\
\text { age } \\
\text { Secu } \\
\text { red } \\
\text { Mar } \\
\text { ks }\end{array}$ & $\%$ & $\begin{array}{l}\text { Lac } \\
\text { una }\end{array}$ & $\begin{array}{l}\text { Aver } \\
\text { age } \\
\text { Secu } \\
\text { red } \\
\text { Mar } \\
\text { ks }\end{array}$ & $\%$ & $\begin{array}{l}\text { Lac } \\
\text { una }\end{array}$ \\
\hline 1 & Social & $\begin{array}{c}11.6 \\
1\end{array}$ & $\begin{array}{l}58 . \\
05\end{array}$ & $\begin{array}{c}41.9 \\
5\end{array}$ & $\begin{array}{c}11.3 \\
1\end{array}$ & $\begin{array}{l}56 . \\
56\end{array}$ & $\begin{array}{c}43.4 \\
3\end{array}$ & $\begin{array}{c}10.0 \\
7\end{array}$ & $\begin{array}{l}50 . \\
37\end{array}$ & $\begin{array}{c}49.6 \\
2\end{array}$ & $\begin{array}{c}10.9 \\
9\end{array}$ & $\begin{array}{l}54 . \\
98\end{array}$ & $\begin{array}{c}45.0 \\
2\end{array}$ \\
\hline 2 & $\begin{array}{l}\text { Econo } \\
\text { mical }\end{array}$ & $\begin{array}{c}11.2 \\
7\end{array}$ & $\begin{array}{l}56 . \\
35\end{array}$ & $\begin{array}{c}43.6 \\
5\end{array}$ & $\begin{array}{c}11.2 \\
3\end{array}$ & $\begin{array}{r}56 . \\
15\end{array}$ & $\begin{array}{c}43.8 \\
5\end{array}$ & 9.74 & $\begin{array}{l}48 . \\
70\end{array}$ & $\begin{array}{c}51.3 \\
0\end{array}$ & $\begin{array}{c}11.1 \\
7\end{array}$ & $\begin{array}{l}55 . \\
85\end{array}$ & $\begin{array}{c}44.1 \\
5\end{array}$ \\
\hline 3 & Gender & $\begin{array}{c}11.6 \\
1\end{array}$ & $\begin{array}{l}58 . \\
05\end{array}$ & $\begin{array}{c}41.9 \\
5\end{array}$ & $\begin{array}{c}11.4 \\
0\end{array}$ & $\begin{array}{c}57 . \\
0\end{array}$ & 43.0 & $\begin{array}{c}10.0 \\
7\end{array}$ & $\begin{array}{l}50 . \\
35\end{array}$ & $\begin{array}{c}49.6 \\
5\end{array}$ & $\begin{array}{c}11.0 \\
2\end{array}$ & $\begin{array}{r}55 . \\
13\end{array}$ & $\begin{array}{c}44.8 \\
7\end{array}$ \\
\hline 4 & $\begin{array}{l}\text { Geogra } \\
\text { phic }\end{array}$ & $\begin{array}{c}11.6 \\
1\end{array}$ & $\begin{array}{l}58 . \\
05\end{array}$ & $\begin{array}{c}41.9 \\
5\end{array}$ & $\begin{array}{c}11.3 \\
1\end{array}$ & $\begin{array}{l}56 . \\
55\end{array}$ & $\begin{array}{c}43.4 \\
5\end{array}$ & $\begin{array}{c}10.0 \\
7\end{array}$ & $\begin{array}{l}50 . \\
35\end{array}$ & $\begin{array}{c}49.6 \\
5\end{array}$ & $\begin{array}{c}10.9 \\
9\end{array}$ & $\begin{array}{l}54 . \\
95\end{array}$ & $\begin{array}{c}45.0 \\
5\end{array}$ \\
\hline & Total & $\begin{array}{c}11.5 \\
2\end{array}$ & $\begin{array}{l}57 . \\
62\end{array}$ & $\begin{array}{c}47.3 \\
8\end{array}$ & $\begin{array}{c}11.3 \\
1\end{array}$ & $\begin{array}{r}56 . \\
56\end{array}$ & $\begin{array}{c}43.4 \\
4\end{array}$ & 9.98 & $\begin{array}{l}49 . \\
93\end{array}$ & $\begin{array}{c}50.0 \\
7\end{array}$ & $\begin{array}{c}11.0 \\
4\end{array}$ & $\begin{array}{l}55 . \\
21\end{array}$ & $\begin{array}{c}44.7 \\
9\end{array}$ \\
\hline
\end{tabular}

The above table represents the data pertaining to the marks of the lacuna of overall listening skill among VIII class students of Guntur, Krishna and Prakasam districts. According to the data Guntur District students have $47.38 \%$ of lacuna whereas Krishna district students have 43.44\%, and Prakasam district students have 50.07\% lacuna. The data 
DOI: https://doi.org/10.24113/ijellh.v9i2.10920

indicates that students from all the districts have $55.21 \%$ of listening skills with $44.79 \%$ lacuna. Krishna district students' lacuna is only $43.44 \%$ because of their geographical and economical advantage. The data also indicates the lacuna of Prakasam district students is very high i.e 50.07\%. Prakasam district students have less than average skills, whereas Krishna district students have more than average skills in listening. On total the students are lagging behind to learn listening skill with $44.79 \%$ lacuna. The practice of listening skill is not given proper place in the syllabus and curriculum. Using of bilingual method at the time of teaching is one more reason for the lack of proper listening skill among the students.

Table 1.2.- The lacuna of overall speaking skill among VIII class students of Guntur, Krishna and Prakasam districts

\begin{tabular}{|c|c|c|c|c|c|c|c|c|c|c|c|c|c|}
\hline \multirow[t]{2}{*}{$\begin{array}{l}\text { S. } \\
\text { No }\end{array}$} & $\begin{array}{l}\text { Name } \\
\text { of The }\end{array}$ & \multicolumn{3}{|c|}{ Guntur } & \multicolumn{3}{|c|}{ Krishna } & \multicolumn{3}{|c|}{ Prakasam } & \multicolumn{3}{|c|}{$\begin{array}{c}\text { Average } \\
\text { Percentage }\end{array}$} \\
\hline & School & $\begin{array}{l}\text { Aver } \\
\text { age } \\
\text { Secu } \\
\text { red } \\
\text { Mar } \\
\text { ks }\end{array}$ & $\%$ & $\begin{array}{l}\text { Lac } \\
\text { una }\end{array}$ & $\begin{array}{l}\text { Aver } \\
\text { age } \\
\text { Secu } \\
\text { red } \\
\text { Mar } \\
\text { ks }\end{array}$ & $\%$ & $\begin{array}{l}\text { Lac } \\
\text { una }\end{array}$ & $\begin{array}{l}\text { Aver } \\
\text { age } \\
\text { Secu } \\
\text { red } \\
\text { Mar } \\
\text { ks }\end{array}$ & $\%$ & $\begin{array}{l}\text { Lac } \\
\text { una }\end{array}$ & $\begin{array}{l}\text { Aver } \\
\text { age } \\
\text { Secu } \\
\text { red } \\
\text { Mar } \\
\text { ks }\end{array}$ & $\%$ & $\begin{array}{l}\text { Lac } \\
\text { una }\end{array}$ \\
\hline 1 & Social & $\begin{array}{c}10.3 \\
6\end{array}$ & $\begin{array}{l}51 . \\
81\end{array}$ & $\begin{array}{c}48.1 \\
9\end{array}$ & $\begin{array}{c}10.1 \\
8\end{array}$ & $\begin{array}{l}50 . \\
90\end{array}$ & $\begin{array}{c}49.1 \\
0\end{array}$ & 7.72 & $\begin{array}{l}38 . \\
62\end{array}$ & $\begin{array}{c}61.3 \\
7\end{array}$ & 9.42 & $\begin{array}{l}47 . \\
10\end{array}$ & $\begin{array}{c}52.9 \\
0\end{array}$ \\
\hline 2 & $\begin{array}{l}\text { Econo } \\
\text { mical }\end{array}$ & $\begin{array}{c}10.3 \\
6\end{array}$ & $\begin{array}{l}51 . \\
80\end{array}$ & $\begin{array}{c}48.2 \\
0\end{array}$ & $\begin{array}{c}10.0 \\
9\end{array}$ & $\begin{array}{l}50 . \\
45\end{array}$ & $\begin{array}{c}49.5 \\
5\end{array}$ & 9.24 & $\begin{array}{l}46 . \\
20\end{array}$ & $\begin{array}{c}53.8 \\
0\end{array}$ & 9.89 & $\begin{array}{l}49 . \\
48\end{array}$ & $\begin{array}{c}40.5 \\
1\end{array}$ \\
\hline 3 & Gender & $\begin{array}{c}10.4 \\
0\end{array}$ & $\begin{array}{r}52 . \\
0\end{array}$ & 48.0 & $\begin{array}{c}10.2 \\
2\end{array}$ & $\begin{array}{l}51 . \\
10\end{array}$ & $\begin{array}{c}48.9 \\
0\end{array}$ & $\begin{array}{c}10.1 \\
8\end{array}$ & $\begin{array}{l}50 . \\
92\end{array}$ & $\begin{array}{c}49.0 \\
8\end{array}$ & $\begin{array}{c}10.2 \\
6\end{array}$ & $\begin{array}{c}51 . \\
33\end{array}$ & $\begin{array}{c}48.6 \\
7\end{array}$ \\
\hline 4 & Geogra & 11.3 & 56. & 43.0 & 11.1 & 55. & 44.5 & 10.0 & 50. & 49.9 & 10.8 & 54. & 45.8 \\
\hline
\end{tabular}


DOI: https://doi.org/10.24113/ijellh.v9i2.10920

\begin{tabular}{|c|c|c|c|c|c|c|c|c|c|c|c|c|c|}
\hline & phic & 9 & 95 & 5 & 0 & 50 & 0 & 1 & 05 & 5 & 3 & 15 & 5 \\
\hline & Total & 10.6 & 53. & 46.8 & 10.3 & 51. & 48.0 & 9.28 & 46. & 53.5 & 10.0 & 50. & 49.5 \\
& 2 & 13 & 7 & 9 & 98 & 2 & & 43 & 7 & 9 & 48 & 2 \\
\hline
\end{tabular}

The above table represents the data pertaining to the marks of the lacuna of overall speaking skill among VIII class students of Guntur, Krishna and Prakasam districts. According to the data Guntur District students have $46.87 \%$ of lacuna whereas Krishna district students have 48.02\%, and Prakasam district students have 53.57\% lacuna. The data indicates that students from all the districts have $50.48 \%$ of speaking skills with $49.52 \%$ lacuna. Guntur District students' lacuna is only $46.87 \%$ because of their geographical and economical advantage. The data also indicates the lacuna of Prakasam district students is very high i.e 53.57\%. Prakasam district students have less than average skills, whereas Guntur District students have more than average skills in speaking. On total the students are lagging behind to learn speaking skill with $49.52 \%$ lacuna. It is noticed that the main reasons for the lacuna of speaking skill are students have fewer opportunities to express their ideas in English language because of mother tongue domination in and around the school.

Conclusion

It is fact that there are many problems of learning primary skills in English language at primary school level. The practice of listening skill is not given proper place in the syllabus and curriculum. Using of bilingual method at the time of teaching is one more reason for the lack of proper listening skill among the students. It is noticed that the main reasons for the lacuna of speaking skill are students have fewer opportunities to express their ideas in English language because of mother tongue domination in and around the school. It is suggested that the task based and target oriented techniques must be include in the teaching and learning process at the high school level. English environment needed to create like English laboratories, English speaking clubs and other cultural activities in the school. 
DOI: https://doi.org/10.24113/ijellh.v9i2.10920

\section{Bibliography}

Chomsky, Noam (1972). Language and Mind. Harcourt Brace Jovanovich. ISBN 978-0- 15549257-8.) Chomsky, Noam (2000). The Architecture of Language. Oxford: Oxford University Press.

Coackly \& Wolvin“A Listening Taxonomy’ (1982).

Baily \& Savage (1994). New Ways in Teaching Speaking

Bright and Marc Gregor (1978) Bright, J. A. \& McGregor, G.P. (1978). Teaching English as a Second Language (p.2). London: Longman.

Dr.S.Priya, (2014) Lacunas Identified in Syllabus Design of English Language teaching in Engineering Colleges: A Study with special Reference to Odisha, India.

State Council for Education Research and Training. 2010 (SCERT)

James Brown. A Discriptive Study of Listening Skill (1949) 